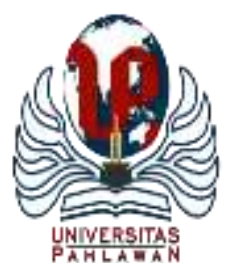

\title{
JURNALBASICEDU
}

Volume 5 Nomor 6 Tahun 2021 Halaman 5001-5013

Research \&Learningin Elementary Education

https://jbasic.org/index.php/basicedu

\section{Analisis Cakupan Literasi Sains dalam Buku Siswa Kelas V Tema 4 Karya Ari Subekti di Sekolah Dasar}

\author{
Ririn Tri Utami ${ }^{1 凶}$, Anatri Desstya ${ }^{2}$ \\ Pendidikan Guru Sekolah Dasar, Universitas Muhammadiyah Surakarta, Indonesia ${ }^{1,2}$ \\ E-mail: ririntriutami99@gmail.com ${ }^{1}, \underline{\text { ad121@ums.ac.id }}^{2}$
}

\begin{abstract}
Abstrak
Literasi sains merupakan suatu kemampuan yang harus dimiliki oleh peserta didik untuk memahami lingkungan hidup dan permasalahan yang dihadapi oleh masyarakat. Dengan demikan, untuk mengetahui ada tidaknya literasi sains maka perlu dilakukan analisis cakupan literasi sains pada buku siswa. Tujuan penelitian untuk menganalisis cakupan literasi sains pada buku siswa kelas V tema 4 karya Ari Subekti. Penelitian menggunakan pendekatan kualitatif dengan desain analisis isi. Teknik pengumpulan data melalui studi dokumentasi. Instrument penelitian berbentuk lembar analisis. Teknik analisis data dengan menganalisis isi buku, memberikan skor pada setiap kemunculan indikator literasi sains, menghitung persentase kesesuaian dari jumlah skor setiap indikator, menghitung rata-rata persentase skor setiap aspek literasi sains. Uji keabsahan data menggunakan uji kreadibilitas dan trianggulasi sumber. Kesimpulan hasil penelitian: aspek sains sebagai batang tubuh ilmu pengetahuan terdapat 79,16\%, aspek sains sebagai jalan untuk menyelidiki terdapat $56,25 \%$, aspek sains sebagai cara berpikir terdapat $31,25 \%$, dan aspek sains sebagai interaksi sains, teknologi dan masyarakat terdapat $27,08 \%$. Nilai persentase rata-rata buku yaitu 48,43\%, termasuk kedalam kategori cukup. Buku lebih menekankan pada aspek sains sebagai batang tubuh ilmu pengetahuan dan tidak menekankan pada penguasaan proses, sikap, dan teknologi, sehingga tidak ada keseimbangan proporsi setiap aspek.
\end{abstract}

Kata Kunci: Analisis, Buku Siswa, Literasi Sains

\begin{abstract}
Scientific literacy is an ability that must be possessed by students to understand the environment and the problems faced by society. Thus, to find out whether there is scientific literacy, it is necessary to analyze the scope of scientific literacy in student books. The purpose of the study was to analyze the scope of scientific literacy in the fifth grade student's book theme 4 by Ari Subekti. The research used a qualitative approach with content analysis design. Data collection techniques were carried out through documentation studies. The research instrument is in the form of an analysis sheet. The data analysis technique is by analyzing the contents of the book, giving a score for each occurrence of the scientific literacy indicator, calculating the percentage of conformity from the total score for each indicator, calculating the average score for each aspect of scientific literacy. Test the validity of the data using the credibility test and triangulation of sources. The conclusion of the research: the aspect of science as the body of science is 79.16\%, the aspect of science as a way to investigate is $56.25 \%$, the aspect of science as a way of thinking is $31.25 \%$, and the aspect of science as the interaction of science, technology and society there are 27.08\%. The average percentage value of the book is $48.43 \%$, which is included in the sufficient category. The book emphasizes more on aspects of science as the body of science and does not emphasize mastery of processes, attitudes, and technology, so that there is no balance in the proportions of each aspect.
\end{abstract}

Keywords:Analysis, Student Books, Scientific Literacy

Copyright (c) 2021 Ririn Tri Utami, Anatri Desstya

$\triangle$ Corresponding author :

Email : ririntriutami99@gmail.com

DOI : https://doi.org/10.31004/basicedu.v5i6.1556

ISSN 2580-3735 (Media Cetak)

ISSN 2580-1147 (Media Online) 


\section{PENDAHULUAN}

Pembelajaran adalah suatu proses dalam menyampaikan pengetahuan yang dilakukan dengan cara menstransfer atau menyampaikan pengetahuan kepada peserta didik. Terutama dalam pembelajaran sains, dimana guru memiliki peran untuk menyampaikan materi sains sehingga mudah untuk dipahami peserta didik melalui strategi mengajar yang kreatif dan inovatif. Di jenjang sekolah dasar, pembelajaran sains memiliki peranan penting untuk mengembangkan sikap ilmiah, kritis, dan mengembangkan rasa ingin tahu. Maka sejalan dengan kurikulum tingkat satuan pendidikan, bawasannya pembelajaran sains penting untuk mengembangkan sikap positif, rasa ingin tahu serta pemahaman akan keterkaitan sains, teknologi, lingkungan, dan masyarakat(Widiana, 2016). Dengan demikian pentingnya menanamkan pembelajaran sains sejak dini bagi peserta didik, untuk membentuk sikap ilmiah serta dapat mengaplikasikan kedalam kehidupan seharihari.

Permanasari (2016), menjelaskan pembelajaran sains merupakan wahana untuk mempelajari diri sendiri dan memahami lingkungan sekitar bagi peserta didik. Di sekolah dasar pembelajaran sains ditujukan untuk melakukan pengamatan disertai percobaan, dengan demikian peserta didik lebih mudah memperoleh pemahaman mengenai lingkungan sekitar. Maka diperlukan pembelajaran yang memuat hakikat sains sebagai produk, proses, maupun sikap. Sejalan dengan pernyataan BSNP (2011) dalam (Sayekti, 2019), sains berhubungan tentang bagaimana mengenal alam sekitar dan tidak sekedar pengetahuan tentang fakta-fakta, konsep-konsep, ataupun prinsip namun meliputi cara penciptaan. Dengan demikian, pembelajaran sains mampu mengembangkan pengetahuan, sikap positif, percaya diri dan keterampilan.

Guna mencapai tujuan pembelajaran sains, seorang guru sebaiknya paham betul tentang hakikat sains serta dapat melaksanakan pembelajaran sesuai kebutuhan maupun kemampuan peserta didik sesuai dengan rancangan didalam kurikulum. Untuk mewujudkan pembelajaran sains yaitu guru hendaknya melaksanakan kegiatan pembelajaran secara inovatif dan menfasilitasi peserta didik dengan sumber belajar yang mendukung, maka mampu mempengaruhi minat belajar sains peserta didik. Proses belajar mengajar tidak terlepas dari komponen-komponen pembelajaran sebagai sumber belajar. Nur (2012), memaparkan sumber belajar merupakan suatu bahan yang diperlukan atau digunakan untuk belajar mengajar baik berbentuk teks, buku, media cetak ataupun elektronik, narasumber, dan lainnya untuk menunjang serta mengoptimalkan hasil belajar. Proses pembelajaran sains dapat berjalan baik jika dilengkapi dengan sumber belajar, salah satunya bahan ajar dalam bentuk buku siswa. Dalam hal ini sesuai dengan pernyataan dari Aqil (2017), buku siswa sebagai sarana penunjang proses pembelajaran yang menjadi sumber pengetahuan bagi peserta didik. Buku siswa merupakan suatu acuan maupun panduan guru beserta peserta didik pada proses pembelajaran yang memiliki fungsi memudahkan dalam mencari materi dan membantu guru untuk menyalurkan materi pembelajaran.

Menurut Hidayati \& Julianto (2018), sumber belajar merupakan faktor utama yang dapat mendukung untuk mengoptimalkan kecakapan yang harus dikuasai peserta didik yaitu dengan buku siswa. Buku siswa memuat berbagai materi pelajaran, informasi, konsep, soal-soal, maupun penerapan pembelajaran pada kegiatan sehari-hari berbentuk satu kesatuan di dalamnya. Pemerintah dalam menerbitkan buku di desain berdasarkan pendekatan ilmiah sesuai dengan tuntutan kurikulum 2013 dengan tujuan menumbuhkan literasi sains bagi peserta didik. Desstya (2015), berpendapat bawasannya buku siswa ialah dokumen rincian dengan standart proses serta kurikulum 2013 yang termuat konsep maupun fakta sebagai produk sains yang dipakai oleh praktisi pendidikan. Maka buku siswa mempunyai standar kualitas buku seperti kelayakan isi, kebahasaan, serta penyajian buku.

Menurut (Permanasari, 2016) pada konteks PISA, literasi sains ialah kemampuan dimana memanfaatkan sains, untuk mencaritahu pertanyaan beserta menyimpulkan yang didukung dengan bukti dilapangan dalam mengambil keputusan berkaitan dengan perubahan akibat dari kegiatan manusia. Literasi 
diartikan sebagai keterampilan membaca dan menulis, berpikir kritis untuk memecahkan persoalan, meningkatkan pengetahuan serta kemampuan dalam berkomunikasi, mengembangkan potensi, serta menumbuhkan partisipasi aktif dimasyarakat.

Nurfaidah (2017), menjelaskan literasi sains sangatlah penting bagi peserta didik dikarenakan untuk memudahkan dalam menyesuaikan diri seiring kemajuan ilmu pengetahuan dan teknologi dimasa depan. Literasi dijadikan pedoman untuk menjawab tantangan di era globalisasi, sehingga diharapkan peserta didik dapat menghadapi tuntutan zaman sebagai problem solver (pemecahan masalah) menjadi individu kreatif, kompetitif, inovatif, kolaboratif dan pribadi berkarakter sesuai teknologi dan sains. Dengan adanya buku yang memadai dan tepat mampu meningkatkan pengetahuan sains, sehingga berdampak pada pengembangan literasi sains peserta didik.

Berdasarkan hasil studi PISA yaitu, tahun 2009 anak-anak di Indonesia memiliki nilai rata-rata komponen literasi sains yaitu 383 dengan menduduki urutan ke-57 dari 65 negara. Selanjutnya, Indonesia di tahun 2012 terdapat diurutan ke-64 atas 65 negara dengan nilai yaitu 382 yang terbilang di bawah skala kemampuan. Dan di 2015 menempati peringkat 64 dari 72 negara mendapat nilai 403. Dari tiga kali survei tersebut dapat menunjukkan bahwa nilai peserta didik di Indonesia dalam konteks literasi sains ternilai dibawah standar internasional dari ketetapan ukuran OECD. Menurut Yuliati (2017), hasil belajar sains rendah ditandai dalam pembelajaran sains belum banyak memberikan kesempatan peserta didik dalam berfikir kritis guna mengembangkan kemampuan. Rendahnya hasil belajar sains dipengaruhi dari penerapan pembelajaran yang terpusat penguasaan konsep saja tanpa memunculkan proses dan sikap, sehingga pembelajaran sains cenderung dihafalkan saja tanpa melibatkan peserta didik dalam percobaan maupun penyelidikan.

Dari permasalahan tersebut, pemilihan buku yang baik dan tepat digunakan sesuai standar yang ditentukan dapat mendukung upaya meningkatkan literasi sains bagi peserta didik. Sejalan pernyataan dari Riadiyani (2009), buku teks pelajaran atau buku siswa berisikan aspek literasi sains yang berdampak pada pengembangan kompetensi serta dapat mendukung literasi sains peserta didik. Buku siswa menjadi salah satu alat untuk meningkatan literasi sains dan menjadi solusi untuk meningkatkan kualitas pendidikan di Indonesia. Calado (2013), mengemukakan perlu dilakukannya penyelidikan tentang potensi buku teks demi mengembangkan literasi sains. Untuk mengetahui buku yang baik dan tepat untuk meningkatkan literasi sains peserta didik maka dilakukan analisis buku yang memuat cakupan tingkatan literasi sains didalamnya.

Dari penelitian terdahulu yang telah dilakukan oleh Çakici (2012), mendapatkan hasil bahwa buku tidak memberikan cakupan seimbang pada aspek literasi sains, buku banyak memuat aspek sains sebagai batang tubuh ilmu pengetahuan. Hal ini sejalan dari penelitian N. Maturraadiyah (2015), buku ajar yang diteliti lebih mengarah pada ilmu pengetahuan seperti konsep, fakta, prinsip, hipotesis, hukum, model, teori, dan mengajak peserta didik untuk mengingat informasi. Dapat disimpulkan bahwa buku lebih banyak memunculkan kategori pengetahuan sains saja, sehingga kurang menekankan pada proses percobaan ataupun penyelidikan.

Penelitian terkait literasi sains, juga sudah dilaksanakan oleh Utaminingsih \& Ibrahim (2018), penelitian ini berkaitan dengan mengujicobakan buku teks berbasis tentang strategi ilmiah untuk mengambarkan validitas, efektivitas, dan kepraktisan buku teks untuk mengajarkan literasi sains. Dari hasil penelitian menunjukkan hasil bahwa buku teks berbasis strategi ilmiah yang di uji cobakan efektif, valid, dan praktis untuk dipakai dalam mengajarkan kemampuan literasi. Berbeda dengan hasil dari Zakiya et al (2017), penelitian menunjukkan keterampilan literasi sains peserta didik terhitung sedikit. Hal ini dikarenakan buku yang dipakai tidak mengarah pada komponen literasi sains.

Dari pemaparan penelitian mengenai analisis buku dan literasi sains, menunjukkan bahwa tidak adanya keseimbangan antara cakupan aspek literasi sains yang terdapat di dalamnya. Buku hanya menekankan pada satu aspek literasi sains saja yaitu lebih banyak menekankan pada sains sebagai ilmu pengetahuan tanpa memunculkan aspek literasi sains yang lainnya. Penelitian tersebut menunjukkan bahwa analisis buku siswa ditinjau dari cakupan aspek literasi sains masih sangat perlu dilanjutkan. Sehingga peniliti perlu menganalisis 
tingkatan cakupan literasi sains pada buku siswa kelas V Tema 4 hasil karya Ari Subekti terbitan Kementerian Pendidikan dan Kebudayaan.

\section{METODE PENELITIAN}

Penelitian menggunakan pendekatan kualitatif, dilengkapi desain analisis isi yang bertujuan menyimpulkan hasil analisis pada buku maupun dokumen, sehingga dapat dideskripsikan secara sistematis, objektif, serta komunikatif. Sebagai sumber data penelitian yaitu Buku Siswa Kelas V (lima) Tema 4 Karya dari Ari Subekti terbitan Kementerian Pendidikan dan Kebudayaan, sedangkan obyek penelitian adalah cakupan literasi sains diantaranya; aspek sains sebagai batang tubuh ilmu pengetahuan, aspek sains sebagai jalan untuk menyelidiki, aspek sains sebagai cara berpikir, dan aspek sains sebagai interaksi sains, teknologi dan masyarakat.

Uji keabsahan data menggunakan uji kreadibilitas dan triangulasi sumber, yang dilaksanakan dengan meningkatkan kecermatan atau ketekunan untuk mengecek kumpulan data yang didapatkan dari berbagai sumber, kemudian disajikan apakah sudah benar atau belum, serta memanfaatkan bahan referensi untuk memperkuat data sehingga dapat dibuktikan kebenaran dan mendapatkan kesimpulan yang disepakati.

Instrumen penelitian berbentuk lembar analisis berisi indikator literasi sains diadaptasi dari instrumen Chiappetta, Fillman \& Sethna dalam Keshni Padayache, 2012 (Meuthia \& Ahmad, 2021). Alat pengumpulan data menggunakan lembar analisis yang berupa tabel pedoman penskoran, tabel deskripsi indikator, dan tabel analisis penyajian setiap aspek literasi sains.

Penelitian ini memerlukan teknik analisis data dengan melalui tahap-tahap diantaranya:

1. Menganalisis isi buku dengan memahami serta membaca setiap unsur teks, pada setiap halaman, dan subtema.

2. Mencocokan setiap pernyataan indikator dibuku siswa dengan tabel penyajian indikator literasi sains.

3. Memberikan skor pada setiap kemunculan indikator literasi sains.

4. Menghitung jumlah skor setiap indikator yang telah dianalisis pada buku siswa.

5. Menghitung persentase kesesuaian dari jumlah total skor setiap indikator literasi sains, dengan menggunakan rumus :

Persentase Kesesuaian $=\frac{\text { Skor } \text { yang diperoleh }}{\text { Skor Maksimal }} \times 100 \%$

6. Menghitung nilai rata-rata persentase skor yang diperoleh dari setiap aspek literasi sains.

7. Menentukan kategori penilaian cakupan literasi sains dan mengkaji hasil dari data yang diperoleh.

\section{HASIL DAN PEMBAHASAN}

Setelah melaksanakan penelitian isi buku siswa kelas V (lima) tema 4 "Sehat itu Penting" hasil Karya dari Ari Subekti yang ditinjau dari cakupan literasi sains mendapatkan hasil penskoran setiap aspek literasi sains pada setiap sub tema yang telah dianalisis maka disimpulkan dalam tabel .

Tabel. Penyajian Skor Setiap Aspek Literasi Sains

\begin{tabular}{rlll}
\multicolumn{1}{ll}{ No } & Aspek Literasi Sains & Jumlah Skor & \% Rata-rata \\
\hline 1. & Sains sebagai Batang Tubuh Ilmu Pengetahuan & 38 & 79,16 \\
\hline 2. & Sains sebagai Jalan Untuk Menyelidiki & 72 & 56,25 \\
\hline 3. & Sains sebagai Cara Berpikir & 60 & 31,25 \\
\hline
\end{tabular}




\begin{tabular}{rlllll}
\hline 4. & $\begin{array}{l}\text { Sains sebagai } \\
\text { Masyarakat }\end{array}$ & Interaksi & Sains, Teknologi dan 39 & 27,08 \\
\hline Jumlah Rata-rata & & & 48,43 \\
\hline
\end{tabular}

Dari tabel didapati tingkatan cakupan literasi sains di buku siswa mempunyai persentase rata-rata dari keseluruhan aspek yang dianalisis yaitu 48,43\%termasuk kedalam kategori cukup, menurut Suharsimi Arikunto dalam Erida, Z., Natalina, M., (2020). Kemunculan aspek paling banyak yaitu sains sebagai batang tubuh ilmu pengetahuan dengan total skor 38 serta persentase rata-rata 79,16\%, sedangkan aspek paling sedikit muncul yaitu sains sebagai interaksi sains, teknologi dan masyarakat skor total 39 beserta persentase rata-rata 27,08\%. Dari hasil tersebut menunjukkan bahwa pada buku siswa cenderung lebih banyak menekankan aspek sains sebagai batang tubuh ilmu pengetahuan. Penelitian ini memiliki kesamaan dengan Ardianto \& Pursitasari (2017), tentang analisis buku berbasis literasi sains, mengambarkan hasil buku belum memberikan kesamaan antara cara menyelidiki, body of knowledge, interaksi IPTEK dan masyarakat. Sains sebagai ilmu pengetahuan lebih mendominasi.

Buku siswa sebagai buku yang mempunyai peran khusus di pembelajaran sains. Menurut kurikulum 2013 buku pelajaran khususnya buku siswa bagi peserta didik SD/MI disusun menjadi tematik terpadu, maka diperlukan analisis secara mendalam untuk materi pembelajaran sains. Mempertimbangkan buku siswa sebagai buku wajib pegangan peserta didik, sehingga harus disajikan dengan sebaik mungkin dengan memaksimalkan kualitas dengan tujuan demi tercapainya tujuan pendidikan nasional dan tujuan kurikulum 2013 (Ruminiati \& Andajani, 2016). Pentingnya peran dan keberadaan buku teks sains terutama buku siswa, sehingga diperlukannya analisis buku siswa dalam meningkatkan kualitas pendidikan di Indonesia serta dapat menunjang literasi bagi peserta didik.

Dari hasil analisis yang telah dipaparkan diatas mendapatkan beberapa temuan yang membedakan antara kemunculan dari ke-empat aspek literasi sains pada buku siswa kelas V (lima) tema 4 "Sehat itu Penting", sebagaimana yang akan dibahas pada setiap aspek yang telah dianalisis berdasarkan gambar .

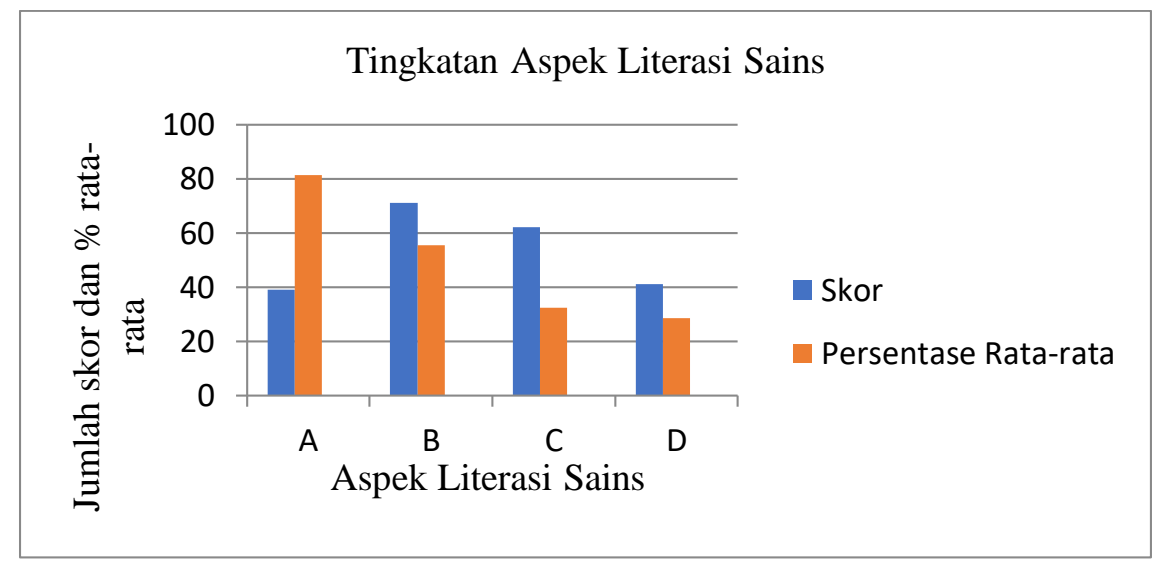

Gambar: Hasil Penskoran dan Persentase Rata-rata

\section{Sains Sebagai Batang Tubuh Ilmu Pengetahuan}

Dari tabel dan gambar dilihat pada aspek ini memiliki tingkatan persentase rata-rata tertinggi dari ketiga aspek literasi sains lainnya dengan nilai sebesar 79,16\% serta jumlah skor keseluruhan subtema sebanyak 38 . Dalam hal ini sejalan dengan penelitian dari Meuthia \& Ahmad (2021), menjelaskan pada aspek sains sebagai batang tubuh ilmu pengetahuan lebih dominan didalam isi buku yang dianalisis. Diperkuat kembali dalam penelitian dari N. Maturraadiyah (2015), menunjukkan hasil bahwa materi yang terdapat didalam buku banyak memunculkan pengetahuan sains seperti konsep, fakta, prinsip, hukum, hipotesis, teori, dan model serta 
meminta peserta didik untuk mengingat informasi. Sedangkan buku ini banyak memfokuskan pada isi materi yang menjelaskan fakta, konsep, prinsip, maupun model. Dengan fakta yang disajikan didalam buku, memberikan gambaran yang kontekstual kepada peserta didik untuk memahami sains.

Buku teks sains yang dijadikan sumber belajar memuat sains sebagai batang tubuh ilmu pengetahuan harus menyajikan, mendiskusikan, dan melibatkan peserta didik dalam menginggat informasi, teori, konsep, hukum, fakta, dan model. Pada dasarnya sains merupakan suatu ilmu pengetahuan mengenai gejala alam yang berupa konsep, fakta, prinsip, maupun hukum yang kebenarannya dapat diuji serta telah melalui proses kegiatan dengan metode ilmiah.

Berdasarkan hasil analisis dapat dilihat bahwa indikator yang banyak mucul yaitu meminta peserta didik untuk mengingat pengetahuan atau informasi faktual dengan skor 14 dengan persentase kesesuaian 87,5\%. Rahmawati et al (2018), menyatakan bahwa pengetahuan faktual yang tinggi yaitu menyampaikan dasar pengetahuan demi membangun pengetahuan tinggi bagi peserta didik dengan memberikan informasi yang lebih luas dan sistematis.

Dapat dilihat pada buku, indikator meminta peserta didik untuk mengingat informasi faktual sebagian besar terpenuhi dan termuat dalam subtema 1,2,3, dan 4. Didalam buku siswa setiap subtema meminta peserta didik untuk mengingat kembali informasi maupun pembelajaran sains yang sudah dibaca sebelumnya khususnya materi peredaran darah. Dicontohkan pada subtema 1 terdapat kegiatan "Ayo Mengamati" meminta peserta didik untuk mengingat kembali materi peredaran darah manusia.

Menurut Lorin W. Anderson dan David R. Krathwohl, mengingat adalah salah satu proses kognitif yang penting untuk bekal dalam belajar bermakna serta untuk menyelesaikan masalah. Dengan demikian didalam buku ini, penyajian proses untuk mengingat ditandai dengan mengulas kembali materi sebelumnya, kemudian menstimulus dengan beberapa pertanyaan dengan guna melatih potensi daya ingat anak akan materi yang sudah dipelajari.

Pada indikator menyajikan fakta-fakta, konsep-konsep, prinsip-prinsip dan hukummemperoleh skor 12 dengan hasil persentase kesesuaian 75\%. Indikator ini lebih banyak pada kegiatan "Ayo Membaca" setiap subtema terdapat sebuah teks bacaan mengenai materi yang dipelajari oleh peserta didik. Contohnya di subtema 1, disajikan teks bacaan manfaat kesehatan organ peredaran darah dari bacaan tersebut peserta didik dapat mengetahui pentingnya menjaga kesehatan organ peredaran darah. Teks bacaan tersebut memiliki tujuan untuk mendukung pemahaman materi yang dipelajari oleh peserta didik pada sajian teks bacaan yang termuat didalam buku yang memuat fakta-fakta, konsep-konsep yang dapat menggambarkan penjelasan dari materi organ peredaran darah serta menyajikan bagaimana pentingnya menjaga kesehatan.

Indikator menyajikan hipotesis-hipotesis, teori dan model memiliki skor total yang sama yaitu 12 dan persentase kesesuaian $75 \%$ dari keseluruhan analisis buku siswa. Setiap subtema pada buku siswa ini menyajikan model-model berupa gambar sistem peredaran darah yang di dalamnya terdapat narasi kalimat untuk menjelaskan gambar model yang dipaparkan, akan tetapi tidak ditambahkan hipotesis ataupun teoriteori yang termuat di dalamnya. Terlihat didalam buku lebih banyak menyajikan gambar model tentang peredaran darah manusia yang disertakan dengan penjelasan penjabaran pada gambar. Hal ini sesuai dengan kompetensi dasar (KD) yaitu memahami organ peredaran darah dan fungsinya pada hewan dan manusia serta cara memelihara kesehatan organ peredaran darah manusia sehingga buku lebih banyak menekankan pada model-model dengan tujuan untuk lebih mudah dipahami peserta didik mengenai pengetahuan ataupun informasi faktual di dalamnya.

Apabila pada buku hanya menekankan materi pengetahuan saja, berdampak pada kurangnya motivasi peserta didik dalam belajar sains yang mempengaruhi minat literasi sainsnya. Sama seperti halnya di dalam buku siswa pada subtema 1,2, dan 3 memuat materi pembelajaran mengenai peredaran darah yang lebih menampilkan konsep, model, fakta, dan prinsip. Dalam teori tidak terdapat ketentuan baku untuk menyusun besar lingkupnya masing-masing kategori literasi sains dibuku ajar. Dengan demikian buku banyak 
menekankan pada aspek sains sebagai batang tubuh ilmu pengetahuan dibandingkan aspek yang lainnya dengan dibuktikan lebih banyak meminta peserta didik untuk mengingat pengetahuan, menyajikan fakta-fakta, konsep, prinsip, model dan pertanyaan-pertanyaan.

\section{Sains Sebagai Jalan untuk Menyelidiki}

Menyelidiki dalam lingkup sains diartikan menumbuhkan kemampuan berpikir serta cara kerja peserta didik untuk menugaskan dalam"menyelidik"(Rusilowati, 2018). Dengan ini melibatkan keaktifan peserta didik dalam pembelajaran dan mencerminkan aspek inkuiri, serta melibatkan proses sains diantaranya; mengamati, mengklasifikasi, pengukuran, perhitungan, menyimpulkan, dan eksperimen.

Dari tabel dan gambar indikator ini mempunyai skor dan persentase rata-rata terbanyak kedua dengan perolehan skor 72 dan persentase rata-rata 56,25\%. Indikator yang banyak muncul di buku siswa yaitu mengharuskan peserta didik untuk menerangkan jawaban dan menggunakan observasi saintifik serta membuat kesimpulan. Dari subtema 1, 2, 3, dan 4 hampir semua memuat indikator tersebut, dengan hasil analisis memperoleh skor masing-masing 16 dengan persentase kesesuaian 100\% sehingga dapat dikatakan bahwa semua indikator terpenuhi. Apabila dibandingkan dengan indikator pada membelajarkan peserta didik untuk membuat kalkulus dan memperoleh informasi dari internet hanya sedikit yang termuat dalam buku siswa. Di dalam buku hanya sedikit melibatkan peserta didik dalam melakukan perhitungan dan informasi materi pembelajaran dari sumber internet.

Berbeda dari hasil penelitian Andriani, N (2017), menganalisis kategori literasi sains pada buku siswa dimana hasil analisis menunjukkan secara garis besar buku siswa banyak memberikan kesempatan peserta didik menjawab pertanyaan dengan penggunaan materi, tabel, dan grafik, meminta peserta didik melakukan perhitungan serta menguraikan argument dari suatu jawaban, mengikutsertakan peserta didik untuk bereksperimen.

Pada indikator mengharuskan peserta didik untuk menerangkan jawaban menjadi salah satu indikator yang banyak muncul pada aspek ini dikarenakan semua subtema menekankan pada indikator ini. Senada dengan pernyataan dari Rusilowati (2018), menyatakan bahwa mengaharuskan peserta didik untuk menerangkan jawaban sebagai upaya untuk melatih dalam menafsirkan dan menyimpulkan gagasan berdasarkan pembelajaran yang telah dipelajari sebelumnya. Penyajian indikator ini didalam buku siswa bertujuan untuk menyimpulkan gagasan mengenai materi yang dipelajari sebelumnya, yang dirangkai dengan kata-kata sendiri.

Salah satu contoh dari indikator ini yaitu pada subtema 1 kegiatan "Ayo Membaca" dimana buku menyajikan teks bacaan untuk disimak oleh peserta didik. Kegiatan ini meminta peserta didik untuk membaca mengenai manfaat kesehatan bagi manusia, kemudian mampu menguraikan manfaat kesehatan, mengulas pentingnya organ peredaran darah, serta mendeskripsikan cara menjaga kesehatan organ peredaran darah.

Indikator menggunakan observasi saintifik dan membuat kesimpulanmerupakan suatu kegiatan peserta didik untuk unjuk kerja yang berdasarkan pada pengamatan maupun observasi dimana peserta didik berpartisipasi langsung dalam diskusi untuk memecahkan masalah yang ada serta mencari solusi dari hasil observasi sehingga dapat mencari jawaban berdasarkan kesimpulan yang didapatkan. Di subtema 3 kegiatan "Ayo Renungkan" peserta didik diminta untuk membuat kesimpulan mengenai bentuk usaha yang dilakukan guna mencegah terjadinya gangguan organ peredaran darah berdasarkan hasil pengamatan yang telah dilakukan dalam kegiatan sehari-hari peserta didik. Dari penyajian kegiatan tersebut lebih banyak peserta didik diberi kesempatan dalam menjelaskan hasil mengidentifikasi maupun observasi yang telah dilakukan.

Indikator kedua yang mempunyai tingkatan persentase rata-rata tertinggi yaitu membelajarkan peserta didik melalui penggunaan bahan materi dengan jumlah skor total yang diperoleh 14 dan persentase kesesuaian 87,5\%. Sebagai contoh indikator yang membelajarkan peserta didik melalui penggunaan bahan materi terdapat di subtema 1 dan 3 kegiatan "Ayo Membaca" yang menyajikan teks tentang manfaat kesehatan organ 
peredaran darah dan teks mengenai manfaat bersepeda dalam memelihara peredaran darah tubuh manusia. Dari teks bacaan tersebut dapat memberikan pembelajaran melalui bahan materi sehingga peserta didik mampu mengidentifikasi dan mengerti bagaimana upaya memelihara kesehatan peredaran darah dalam tubuh. Gucluer \& Kesercioglu (2012), mengemukakan penggunaan teks pada pembelajaran sains lebih efektif digunakan guna menanamkan konsep ilmiah. Indikator ini menekankan keaktifan peserta didik untuk mengobservasi, mengumpulkan data, dan menarik kesimpulan. Dimana peserta didik aktif dalam mengetahui pertanyaan, mendapatkan pengetahuan baru sehingga dapat mengumpulkan data, menjelaskan dan mengambil kesimpulan berdasarkan apa yang sudah diamati.

Pada indikator analisis dan interprestasi data memiliki skor total 12 dan persentase kesesuaian $75 \%$ dari hasil tersebut dapat dikatakan bahwa pada indikator ini masih dapat ditemukan dibuku siswa apabila dibandingkan dengan indikator lainnya yang tidak termuat didalam buku. Pada subtema 1 terdapat kegiatan "Ayo Mengamati" didalam buku siswa telah disajikan gambar paru-paru dimana pada gambar tersebut peserta didik mampu menggali informasi dengan menganalisis dan menyelidiki jenis gangguan alat peredaran darah serta mencari tahu penyebab gangguan alat peredaran darah.

Selanjutnya indikator membelajarkan peserta didik melalui penggunaan tabel dan grafik mempunyai skor total 6 dan persentase kesesuaian 37,5\%. Tingkatan persentase kesesuaian pada indikator ini terbilang rendah karena didalam buku siswa lebih banyak menggunakan gambar sebagai media untuk memberikan contoh kepada peserta didik. Indikator yang memiliki nilai yang rendah lainya yaitu pada indikator melibatkan peserta didik untuk bereksperimen dengan jumlah skor 4 dan persentase kesesuaian 25\%. Dikarenakan indikator hanya dimunculkan pada subtema 4 saja yaitu melibatkan peserta didik dalam kegiatan "Ayo Mencoba" dimana pada kegiatan ini melibatkan peserta didik untuk melakukan percobaan dalam membuat alat sederhana.

Indikator yang jarang ditemui di dalam buku siswa yaitu indikator membelajarkan peserta didik untuk membuat kalkulus. Indikator ini hanya ditemui pada subtema 1 yaitu kegiatan "Ayo Mencoba" pada kegiatan ini melibatkan peserta didik dalam mencoba merasakan denyut nadi atau denyut jantungnya kemudian peserta didik dapat melakukan perhitungan kecepatan denyut nadi dan denyut jantung. indikator memperoleh informasi dari internet. Setelah melakukan analisis buku mendapatkan skor 3, dengan persentase kesesuaian $18,75 \%$. Akan tetapi pada Indikator ini kurang ditemukan di buku siswa dikarenakan materi sains kebanyakan sudah dijabarkan dan dijelaskan di buku sehingga tidak banyak informasi tambahan dari internet. Hanya saja peserta didik diminta untuk mencari informasi lebih banyak dari sumber internet tentang ulasan materi organ peredaran darah.

Berdasarkan berbagai kegiatan tersebut dapat disimpulkan bahwa didalam buku siswa pada aspek sains sebagai jalan menyelidiki lebih banyak menekankan pada indikator mengharuskan peserta didik untuk menjelaskan jawaban dan menggunakan observasi saintifik beserta membuat kesimpulan dibandingkan dengan indikator yang lainnya.

\section{Sains Sebagai Cara Berpikir}

Sains adalah suatu kegiatan manusia ditandai dengan proses berpikir yang terjadi didalam pikiran. Sedangkan pekerjaan seorang ilmuwan berkaitan dengan akal, menggambarkan keingitahuan manusia dan keinginan untuk memahami gejala alam yang terjadi. Menurut Rusilowati (2018), menyatakan bahwa aspek ini diidentifikasi dari teks yang terdapat di buku sains berupa gambaran atau ilustrasi secara umum serta ilmuwan melaksanakan eksperimen. Pada aspek ini dapat sebagai proses berpikir, penalaran, dan merefleksikan peserta didik ketika terlibat kegiatan ilmiah.

Berdasarkan hasil penskoran tabel dan gambar diatas, diperoleh skor 60 dengan persentase rata-rata $31,25 \%$. Dari hasil analisis menunjukkan kurangnya aktivitas peserta didik dalam proses beripikir baik pada pertanyaan ataupun isi materi didalam buku siswa. Serupa dengan penelitian dari Wahyu et al (2016), 
bawasannya hasil penelitian diperoleh sedikit kegiatan mengajak peserta didik dalam berpikir tinggi dilihat dari isi materi atau pertanyaan. Disebabkan muatan buku siswa sedikit ditemukan pertanyaan untuk melibatkan peserta didik berpikir sesuai dengan aspek sains sebagai cara berpikir seperti halnya disajikan pertanyaan-pertanyaan yang memancing rasa tahu ataupun berpikir kritis sesuai fenomena yang ada.

Indikator yang lebih dominan muncul didalam buku siswa yaitu mendiskusikan fakta dan bukti dengan jumlah skor total 16 dan persentase kesesuaian 100\%. Pada setiap subtema lebih banyak menekankan pada mendiskusikan fakta dan bukti yang ditunjukkan didalam buku siswa setiap akhir materi pembelajaran peserta didik diminta mendiskusikan bersama tentang persoalan yang telah disediakan didalam buku. Menurut Mochamad Irsyan et al (2013), kegiatan diskusi didasarkan pada fakta yang teruji kebenarannya serta dapat dilihat maupun diamati dan didukung bukti informasi yang ada. Maka di dalam buku siswa lebih banyak menekankan pada kegiatan diskusi yang melibatkan peserta didik dalam proses memecahkan suatu masalah yang dihadapi berdasarkan fakta maupun bukti yang ada.

Pada temuan di subtema 4 terdapat kegiatan "Ayo Mencoba" peserta didik bekerja sama dengan temantemannya untuk mendiskusikan mengenai percobaan membuat alat sederhana peredaran darah manusia yang dipraktekan secara bersama-sama. Dari kegiatan tersebut melatih peserta didik untuk aktif bekerja sama serta berdiskusi untuk bertukar gagasan maupun pikiran.

Indikator menekankan sifat empiris dan objektivitas ilmu sains, memperoleh hasil skor 13 dan persentase kesesuaian $81,25 \%$. Buku siswa lebih banyak menekankan pada sifat empiris dan objektivitas dimana peserta didik diminta untuk mengidentifikasi, mengumpulkan data, menjelaskan, maupun mengambil kesimpulan dari proses pengamatan mengenai analisis materi peredaran darah. Dari semua subtema di buku siswa banyak melatih keaktifan maupun berpikir kritis peserta didik dalam pengamatan maupun percobaan dari hasil mempelajari lingkungan sekitar. Disajikannya sifat empiris dan objektivitas sains diharapkan dapat memberikan kesadaran bagi peserta didik bahwa sains merupakan hal yang sangat berkaitan erat dengan kehidupan serta dapat dilihat secara langsung.

Peserta didik disajikan kegiatan "Ayo Membaca", peserta didik dapat mencari tahu jenis-jenis gangguan dari alat peredaran darah, serta dapat mengetahui faktor gangguan pada alat peredaran darah. Disajikan teks bacaan dapat melatih peserta didik untuk menjelaskan bagaimana usaha yang dilakukan guna mencegah gangguan pada alat peredaran darah, sehingga peserta didik dapat mengetahui informasi teks bacaan. Hal ini penting untuk digambarkan kepada peserta didik dalam menarik minat untuk belajar sains dan memotivasi peserta didik untuk lebih memperhatikan kesehatan organ peredaran darah.

Indikator memberikan sebab dan akibat memperoleh skor 12, dengan persentase kesesuaian $75 \%$. Indikator ini ditemukan pada setiap subtema dalam buku siswa kecuali pada subtema 4 yang tidak memuat indikator ini. Di dalam buku siswa lebih banyak memberikan hubungan sebab dan akibat pada materi pembelajaran sains khususnya pada materi peredaran darah manusia, gangguan kesehatan pada organ peredaran darah, serta bagaimana bentuk memelihara kesehatan organ peredaran darah manusia dengan "Ayo Membaca" dijelaskan secara rinci di dalam buku siswa disertai dengan hubungan sebab dan akibat. Dari teks tersebut diharapkan peserta didik dapat mencaritahu informasi berdasarkan teks bacaan, serta paham akan faktor-faktor yang mempengaruhi kesehatan. Hal ini membantu peserta didik untuk mengetahui bagaimana penyebab yang mempengaruhi kesehatan, sehingga memberikan pandangan bagi peserta didik mengenai cara menjaga kesehatan untuk diaplikasikan dalam kehidupan sehari-hari.

Sama halnya dengan indikator menunjukkan sikap skeptic dan kritis dengan perolehan skor 12 dengan persentase kesesuaian $75 \%$. Indikator ini lebih menekankan pada sikap keingintahuan peserta didik terhadap hal-hal yang belum pasti serta mencari jawaban terhadap suatu permasalahan atau kejadian yang diamati, sehingga dapat menggali kemampuan kritis peserta didik. Terlihat pada buku siswa subtema 1 dengan kegiatan "Ayo Mengamati” disediakan media sebuah gambar dengan tujuan untuk menstimulus berpikir kritis 
bagi peserta didik untuk memahami gambar, sehingga meningkatkan keingintahuan melalui mengidentifikasi dan menguraikan beberapa bagian jantung yang turut dalam peredaran darah.

Sedangkan pada indikator menggambarkan imajinasi dan kreativitas manusia dengan skor 5 dan persentase kesesuaian 31,25\%. Didapatkan materi mengarahkan peserta didik untuk mengembangkan daya imajinasi maupun kreativitas peserta didik terlihat di subtema 1 kegiatan "Ayo Berkreasi”. Peserta didik diarahkan mengambar sistematika alur peredaran darah disertai keterangan pada gambar.

Sementara itu, indikator menunjukkan perkembangan historis dari sebuah ide setelah dianalisis memperoleh skor 2 dengan persentase kesesuaian 12,5\%, kecilnya persentase kesesuaian pada indikator dikarenakan indikator jarang ditemukan pada setiap subtema dan hanya ditemukan di subtema 1 pembelajaran 5 memberikan ulasan sedikit mengenai penelitian dari para peneliti terdahulu serta di subtema 4 peserta didik diminta praktik membuat alat sederhana demi mengetahui peredaran darah pada manusia kemudian peserta didik melakukan percobaan dari alat sederhana yang telah dibuat.

Ada beberapa indikator yang tidak ditemukan didalam buku siswa diantaranya yaitu: menggambarkan bagaimana seorang ilmuwan melakukan eksperimen. Isi dari buku tidak menyajikan bagaimana seorang ilmuan melakukan ekperimen sehingga tidak memberikan ulasan materi tentang bagaimana menggambarkan cara yang dilakukan seorang ilmuwan untuk meningkatkan kepahaman pelajaran maupun percobaan. Pentingnya sebuah proses untuk membelajarkan peserta didik. Menurut Rusilowati (2018), dikarenakan munculnya ilmu pengetahuan diawali dengan proses berpikir, belajar, disertai berkreasi. Indikator mengilustrasikan penggunaan asumsi-asumsi, menunjukkan bagaimana ilmu sains berjalan dengan pertimbangan induktif dan deduktif, menyajikan metode ilmiah dan pemecahan masalah, mengambarkan karakteristik saintis, dan menunjukkan berbagai jalan untuk memahami dunia. Pada indikator tersebut tidak dimunculkan didalam buku siswa.

\section{Sains Sebagai Interaksi Sains, Teknologi dan Masyarakat}

Menurut Rusilowati (2018), aspek ini sebagai pengaplikasian sains dan teknologi terhadap manusia baik berdampak positif maupun negatif. Pada dasarnya aspek sebagai interaksi sains, teknologi dan masyarakat merupakan aspek pembelajaran membahas mengenai pelaksanaan sains pada kehidupan seharihari. Maka teknologi dijadikan salah satu unsur pembelajaran dikarenakan sains dan teknologi memiliki keterkaitan satu sama lain.

Pentingnya aspek sains sebagai interaksi sains, teknologi dan masyarakat tidak seimbang dari analisis yang telah dilaksanakan peneliti mendapatkan data yang terdapat pada tabel dan gambar diketahui aspek sains sebagai interaksi Sains, teknologi dan masyarakat memperoleh jumlah skor 39 dan persentase rata-rata 27,08\%. Dari hal tersebut dapat dikatakan bahwa aspek sains sebagai Interaksi Sains, Teknologi dan Masyarakat termasuk persentase terkecil apabila dibandingkan aspek lainnya. Dengan ini menjelaskan aspek sains sebagai Interaksi Sains, Teknologi jarang muncul dan kurang dicantumkan di dalam buku siswa.

Sama seperti penelitian dari Nurfaidah (2017), menjelaskan bawasannya aspek interaksi sains, teknologi dan masyarakat hasil temuan memperlihatkan buku teks IPA kelas V sekolah dasar jarang ditemui didalam buku. Pada aspek ini yang lebih muncul didalam buku siswa yaitu pada indikator mendiskusikan masalah-masalah sosial yang berhubungan dengan ilmu social atau teknologiyang terdapat pada di subtema 1, 2, dan 3. Indikator ini mempunyai jumlah skor total dari keseluruhan subtema yaitu 13 dengan persentase kesesuaian $81,25 \%$.

Sebagai contoh pada kegiatan "Ayo Renungkan" subtema 1 di dalam buku siswa dimana peserta didik mengidentifikasi upaya dalam menjaga kesehatan organ peredaran darah, kemudian peserta didik diminta untuk mendiskusikan bersama mengenai suatu permasalahan yang ada dan mencari solusi maupun jawaban dari permasalahan tersebut. Kegiatan lebih memperlihatkan sikap peserta didik setelah memahami materi dan melatih peserta didik untuk berdiskusi sebagai bentuk kerja sama dengan teman sebaya sehingga dapat 
mengungkapkan pendapat masing-masing yang pada akhirnya peserta didik dapat menjelaskan hasil temuan dari diskusi.

Adapun pada indikator menggambarkan kegunaan ilmu sains dan teknologi bagi masyarakat hanya memperoleh skor 8 dengan persentase kesesuaian 50\%, indikator hanya dimunculkan di subtema 2, 3, dan 4 saja. Pada isi buku siswa yang menggambarkan kegunaan ilmu sains dan teknologi termuat dibeberapa subtema. Buku siswa sudah memberikan ulasan yang rinci terkait dengan contoh kegunaan dari ilmu sains dan teknologi di masyarakat. Sebagai contoh terdapat teks cerita mengenai olahraga bersepatu roda menjadi salah satu cara untuk menjaga kesehatan. Pada teks bacaan tersebut sudah mengimplementasikan indikator untuk dipahami peserta didik. Disajikan contoh olahraga bersepatu roda ini menjadi salah satu bentuk fungsi ilmu sains dan teknologi terhadap masyarakat. Dari menghubungkan dan menyimak teks cerita tersebut, akan berdampak pada proses berpikir peserta didik untuk lebih menjaga kesehatan dengan cara berolahraga.

Indikator menunjukkan dampak sosial dan budaya dengan perolehan skor 9, dan persentase kesesuaian $56,25 \%$ terdapat pada subtema 1,2 , dan 3 . Pada indikator ini didalam buku siswa sudah menunjukkan dampak sosial dan budaya, sebagaimana contoh setelah mempelajari cara memelihara kesehatan organ peredaran darah manusia, peserta didk dapat mengaplikasikan materi yang didapatkan kedalam lingkungan sekitar bersama orang tua maupun anggota keluarga dirumah dengan membelajarkan peserta didik untuk membuat jadwal olahraga dengan tujuan menjaga kesehatan peredaran darah. Secara tidak langsung kegiatan ini dapat menerapkan sikap disiplin peserta didik untuk olahraga sesuai jadwal, sehingga akan menjadi suatu kebiasaan yang diterapkan di rumah.

Indikator menunjukkan interaksi dengan publik atau kerjasama dengan teman sebaya memperoleh skor 5 dengan persentase kesesuaian 31,25\% ditunjukkan pada subtema 1 terdapat kegiatan diskusi dengan teman sebaya sehingga menunjukkan kerja sama antar peserta didik dalam menyelesaikan permasalahan yang ada. Di dalam buku siswa terdapat beberapa kegiatan yang melibatkan peserta didik untuk diskusi maupun kerja sama dengan teman sebaya maupun orang tua di rumah.

Indikator etika sains memperoleh skor 4 dan persentase kesesuaian $25 \%$, setiap subtema terdapat indikator ini walaupun hanya sebagian saja. Sebagai salah satu contoh pernyataan etika sains yang terdapat di dalam buku yang mengingatkan bawasannya kesehatan peredaran darah penting dijaga karena banyak yang mengabaikan akan kesehatan organ peredaran darah. Dari pernyataan tersebut dapat menjadi renungan peserta didik untuk lebih memperhatikan kesehatan organ peredaran darah dan juga dapat menerapkan materi tentang menjaga kesehatan peredaran darah yang sudah dipelajari sebelumnya.

Indikator-indikator yang tidak ditemukan didalam buku siswa yaitu; menunjukkan efek negatif dari ilmu sains dan teknologi bagi masyarakat, menyebutkan karir-karir dan pekerjaan dibidang ilmu dan teknologi, memberikan konstribusi terhadap keberagaman, dan limitasi sains. Setidaknya, pengaruh negatif sains, teknologi dan masyarakat ditampilan didalam buku, sehingga peserta didik mengerti bahayanya sains dan teknologi apabila tidak dipakai dengan tepat. Akan tetapi hal ini tidak ditemukan di dalam buku, sehingga perlu banyak ditampilkan bagaimana penggunaan dan contoh peran sains dalam kehidupan sehari-hari. Dengan demikian bertujuan supaya peserta didik paham terhadap manfaat dan pengaruh sains terhadap kehidupan di lingkungan sekitar, sehingga tidak hanya paham sebatas konten saja.

\section{KESIMPULAN}

Dari pemaparan hasil dan pembahasan dapat disimpulkan buku siswa kelas V (lima) tema 4 karya Ari Subekti, dengan perolehan persentase rata-rata 48,43\% dari keseluruhan buku yang dianalisis menunjukkan tidak adanya keseimbangan proporsi pada setiap aspek literasi sains yang disajikan sehingga dapat dikatakan bahwa buku memiliki kriteria penilaian cakupan literasi sains dengan kategori cukup. Isi buku menunjukkan banyak menyajikan aspek sains sebagai batang tubuh ilmu pengetahuan memperoleh persentase rata-rata 
5012 Analisis Cakupan Literasi Sains dalam Buku Siswa Kelas V Tema 4 Karya Ari Subekti di Sekolah Dasar - Ririn Tri Utami, Anatri Desstya

DOI : https://doi.org/10.31004/basicedu.v5i6.1556

sebanyak 79,16\%, kemudian aspek sains sebagai jalan untuk menyelidiki sebesar 56,25\%, aspek sains sebagai cara untuk berpikir sebesar $31,25 \%$ dan aspek interaksi sains, teknologi dan masyarakat mempunyai tingkatan cakupan literasi sains terendah yaitu sebesar $27,08 \%$.

\section{DAFTAR PUSTAKA}

Andriani, N., I. (2017). Analisis Kategori Literasi Sains Untuk Konten Fisik Pada Buku Siswa Mata Pelajaran Ipa Kelas Vii Smp/Mts. Prosiding Seminar Nasional Pendidikan Ipa 2017 Stem Untuk Pembelajaran Sains Abad 211. Palembang, 23 September 2017, 2013(53), 664-672.

Aqil, D. I. (2017). Literasi Sains Sebagai Konsep Pembelajaran Buku Ajar Biologi Di Sekolah. Wacana Didaktika, 5(02), 160. Https://Doi.Org/10.31102/Wacanadidaktika.V5i02.59

Ardianto, D., \& Pursitasari, I. D. (2017). Do Middle School Science Textbook Enclose An Entity Of Science Literacy? Jhss (Journal Of Humanities And Social Studies), 1(1), 24-27. Https://Doi.Org/10.33751/Jhss.V1i1.369

Çakici, Y. (2012). Exploring Turkish Upper Primary Level Science Textbooks' Coverage Of Scientific Literacy Themes. Egitim Arastirmalari - Eurasian Journal Of Educational Research, 49, 81-102.

Calado, F. M. (2013). A Reflection On Distorted Views Of Science And Technology In Science Textbooks As Obstacles To The Improvement Of Students' Scientific Literacy. European Journal Of Educational Research, 2(3), 51-68. Https://Doi.Org/10.12973/Eu-Jer.2.2.51

Desstya, A. (2015). Keterampilan Proses Sains Dan Pembelajaran Ipa Di Sekolah Dasar (Telaah Buku Siswa Kelas Iv Sd Tema 2 Karya Sumini). Profesi Pendidikan Dasar, 2(2), 95-102.

Erida, Z., Natalina, M., \& D. (2020). Analysis Of Science Text Book For Vii Grade Junior High School In Erlangga Book And Test Question. Jom Fkip, 7, 1-13.

Gucluer, E., \& Kesercioglu, T. (2012). The Effect Of Using Activities Improving Scientific Literacy On Students' Achievement In Science And Technology Lesson. Online Submission, 1(1), 8-13. Http://Search.Ebscohost.Com/Login.Aspx?Direct=True\&Db=Eric\&An=Ed534087\&Site=Ehost-Live

Hidayati, F., \& Julianto. (2018). Penerapan Literasi Sains Dalam Pembelajaran Ipa Di Sekolah Dasar Untuk Meningkatkan Kemampuan Berfikir Kritis Siswa Dalam Memecahkan Masalah. In Seminar Nasional Pendidikan (Pp. 180-184).

Meuthia, H., \& Ahmad, R. (2021). Analisis Aspek-Aspek Literasi Sains Pada Buku Kurikulum 2013 Tema 1 Kelas Iv Sd. Jems (Jurnal Edukasi Matematika Dan Sains), 9(1), 86-98. Https://Doi.Org/10.25273/Jems.V9i1.8667

Mochamad Irsyan, S., Setiawan, A., \& Rusnayati, H. (2013). Analisis Buku Ajar Fisika Sma Kelas X Di Kota Bandung Berdasarkan Komponen Literasi Sains. Prosidings Seminar Nasional Fisika 2013, 94-102.

N. Maturraadiyah, A. R. (2015). Analisis Buku Ajar Fisika Sma Kelas Xii Di Kabupaten Pati Berdasarkan Muatan Literasi Sains. Upej Unnes Physics Education Journal, 4(1). Https://Doi.Org/10.15294/Upej.V4i1.4731

Nur, F. M. (2012). Pemanfaatan Sumber Belajar Dalam Pembelajaran Sains Kelas V Sd Pada Pokok Bahasan Makhluk Hidup Dan Proses Kehidupan. Jurnal Penelitian Pendidikan, 13(1), 67-78.

Nurfaidah, S. S. (2017). Analisis Aspek Literasi Sains Pada Buku Teks Pelajaran Ipa Kelas V Sd. Analisis Aspek Literasi Sains Pada Buku Teks Pelajaran Ipa Kelas V Sd, 4(1), 56-66. Https://Doi.Org/10.23819/Mimbar-Sd.V4i1.5585

Permanasari, A. (2016). Stem Education: Inovasi Dalam Pembelajaran Sains. Stem Education: Inovasi Dalam Pembelajaran Sains, 2016-2023. Https://Media.Neliti.Com/Media/Publications/173124-Id-StemEducation-Inovasi-Dalam-Pembelajara.Pdf 
5013 Analisis Cakupan Literasi Sains dalam Buku Siswa Kelas V Tema 4 Karya Ari Subekti di Sekolah Dasar - Ririn Tri Utami, Anatri Desstya

DOI : https://doi.org/10.31004/basicedu.v5i6.1556

Rahmawati, A., Ariyanto, J., \& Sari, D. P. (2018). Profil Komposisi Jenis Dimensi Pengetahuan Dalam Kegiatan Pembelajaran Biologi Pada Materi Sistem Reproduksi Di Kelas Xi Mipa Sma X Surakarta. Proceeding Biology Education Conference, 15(1), 554-558.

Ruminiati, R., \& Andajani, K. (2016). Analisis Kesesuaian Isi Buku Tematik Kelas Iv Sekolah Dasar Dengan Pendidikan Karakter, Dan Pendekatan Scientific. Sekolah Dasar: Kajian Teori Dan Praktik Pendidikan, 25(1), 27-36. Https://Doi.Org/10.17977/Um009v25i12016p027

Rusilowati, A. (2018). Asesmen Literasi Sains: Analisis Karakteristik Instrumen Dan Kemampuan Siswa Menggunakan Teori Tes Modern Rasch Model. Prosiding Seminar Nasional Fisika Universitas Riau Ke-3, September, 2-15.

Sayekti, I. C. (2019). Analisis Hakikat Ipa Pada Buku Siswa Kelas Iv Sub Tema I Tema 3 Kurikulum 2013. Profesi Pendidikan Dasar, 1(2), 129-144. Https://Doi.Org/10.23917/Ppd.V1i2.9256

Utaminingsih, S., \& Ibrahim, M. (2018). The Development Of Textbook Based Approach To Teach Scientific Literacy At 5th Grade. 212, 197-201. Https://Doi.Org/10.2991/Icei-18.2018.43

Wahyu, E., Fathurohman, A., \& Markos, S. (2016). Analisis Buku Siswa Mata Pelajaran Ipa Kelas Viii Smp/Mts Berdasarkan Kategori Literasi Sains. Jurnal Inovasi Dan Pembelajaran Fisika, 3(2), 14-24.

Widiana, I. W. (2016). Pengembangan Asesmen Proyek Dalam Pembelajaran Ipa Di Sekolah Dasar. Jpi (Jurnal Pendidikan Indonesia), 5(2), 147. Https://Doi.Org/10.23887/Jpi-Undiksha.V5i2.8154

Yuliati, Y. (2017). Literasi Sains Dalam Pembelajaran Ipa. Jurnal Cakrawala Pendas, 3(2), 21-28. Https://Doi.Org/10.31949/Jcp.V3i2.592

Zakiya, H., Sinaga, P., \& Hamidah, I. (2017). The Effectiveness Of Multi Modal Representation Text Books To Improve Student's Scientific Literacy Of Senior High School Students. Aip Conference Proceedings, 1848. Https://Doi.Org/10.1063/1.4983957 